\title{
Efeito do diazóxido na pancreatite aguda necrotizante experimental
}

\author{
Effect of diazoxide in experimental acute necrotizing pancreatitis
}

\section{Acadêmica: Roberta de Oliveira Andrade \\ Orientadores: Heraldo Possolo de Souza, Marcia Kiyomi Koike, Tiago Kunitake}

Introdução: A pancreatite aguda (PA) é grave e cursa com inflamação local e sistêmica. O diazóxido tem efeito antiinflamatório em modelos experimentais e clínicos.

Objetivos: Avaliar efeito do diazóxido na mortalidade, lesão pancreática e resposta inflamatória dos animais submetidos à PA.

Métodos: A PA foi induzida injetando ácido taurocólico 2,5\% via ducto bileopancreático. Foram utilizados 58 ratos Wistar machos pesando de $200 \mathrm{~g}$ a $400 \mathrm{~g}$ divididos aleatoriamente em dois grupos: Controle: administração venosa prévia de salina estéril ( $3 \mathrm{~mL} / \mathrm{kg})$; Tratamento: administração venosa prévia de diazóxido $45 \mathrm{mg} / \mathrm{kg}$. A curva de mortalidade ( $\mathrm{n}=38$ ) foi estudada observando-se os ratos por 72 horas e analisada pelo teste de Log-rank (Mantel-Cox). Para estudo das lesões pancreáticas e da inflamação sistêmica, os ratos $(n=20)$ foram sacrificados 3 horas após indução da PA, mensurou-se volume de ascite, coletou-se sangue e pâncreas. Lesão histológica foi avaliada segundo critérios de Schmidt e analisada pelos testes $t$ e de Mann-Whitney. Citocinas plasmáticas foram dosadas por multiplex e analisadas pelo teste $t$ de Student, bem como volume de ascite.

Resultados: Mortalidade em 72 horas foi 33\% no controle e $60 \%$ no tratamento, $p=0,07$. A necrose acinar foi menor no grupo Tratamento comparado ao Controle $(3,5(3,0-3,5)$ vs. $3,75(3,5-4,0)$, p=0,015). Os demais critérios histológicos foram similares. O nível de marcadores inflamatórios foi igual entre os grupos. O volume de ascite foi igual nos dois grupos, $\mathrm{p}=0,172$.

Conclusão: $O$ tratamento com diazóxido reduziu a necrose acinar na pancreatite aguda experimental, porém não alterou a mortalidade em 72 horas.

Palavras-chave: Pancreatite; Diazóxido; Modelos animais.

Introduction: Acute pancreatitis (AP) is severe and progresses with local and systemic inflammation. Diazoxide has antiinflammatory effects in experimental and clinical models.

Purpose: To assess diazoxide effects in mortality, pancreatic injury and inflammatory response of the animals submitted to PA.

Methods: The PA was induced by injecting 2.5\% taurocholic acid via bileopancreatic duct. 58 male Wistar rats weighing $200 \mathrm{~g}$ to $400 \mathrm{~g}$ were utilized and randomly divided into two groups: Control: previous intravenous administration of sterile saline ( $3 \mathrm{ml} / \mathrm{kg}$ ); Treatment: previous intravenous administration ( 15 minutes) of diazoxide $45 \mathrm{mg} / \mathrm{kg}$. The study of mortality $(n=38)$ was performed by observing the mice for 72 hours and analyzed by Log-rank test (Mantel-Cox). To study pancreatic lesions and systemic inflammation, rats $(n=20)$ were sacrificed 3 hours after induction of AP, ascites volume was verified 
and blood and pancreas were collected. Pancreatic injury has been assessed according to Schmidt's criteria and analyzed by $t$ test and Mann-Whitney; plasma cytokines were evaluated by multiplex and analyzed by $t$ test, as well as ascites volume.

Results: Mortality at 72 hours was $33 \%$ in the control and $60 \%$ in the treatment with $\mathrm{P}=0.07$. Acinar necrosis was lower in treatment group compared to control (3.5 (3.0-3.5) vs. 3.75 (3.5-4.0), $\mathrm{p}=0.015)$. Other histological criteria were similar. The level of inflammatory markers was similar between groups. The volume of ascites was similar in both groups, $\mathrm{p}=0.172$.

Conclusion: Treatment with diazoxide reduced acinar necrosis in experimental acute pancreatitis, but did not affect mortality in 72 hours.

Keywords: Pancreatitis; Diazoxide; Animal models. 